\title{
Efecto de las gemas en la resistencia a flexión de piezas enterizas de madera
}

\section{The effect of wanes on the bending strength of solid timber beams}

\author{
F. Arriaga Martitegui(*), M. Esteban Herrero(*), R. Argüelles Álvarez(*), I. Bobadilla Maldonado(*) \\ y G. Íñiguez González(*)
}

Recepción/Received: 26-X-06

Aceptación/Accepted: 25-I-07

RESUMEN

Se ha realizado un análisis teórico del efecto de las gemas en la capacidad resistente de vigas de madera debida a la disminución de la sección con respecto a la sección rectangular, evaluando la pérdida de resistencia a flexión equivalente. Por otro lado, se han ensayado 84 piezas de pino silvestre (Pinus sylvestris L.) y pino pinaster (Pinus pinaster Ait.) de gruesa escuadría procedente de edificios antiguos, de las que 51 presentaban el defecto de las gemas. Se ha obtenido la resistencia a flexión, el módulo de elasticidad a flexión y la densidad mediante ensayo según norma EN 408.

Las propiedades mecánicas de las piezas con gemas y sin gemas resultan muy similares y no hay diferencias estadísticamente significativas. El efecto de pérdida de sección debida a la gema parece compensarse con la mayor continuidad de las fibras en la superficie de la pieza y con un efecto de forma de la sección. Una consecuencia práctica que se deriva de este hecho es que podrían despreciarse las gemas (hasta un límite) en la clasificación de piezas de madera de gruesa escuadría en estructuras existentes, donde es muy frecuente este defecto, evitando el elevado rechazo que implica la aplicación de las normas actuales de clasificación visual.

Palabras clave: madera, propiedades mecánicas, defectos, gemas, clasificación visual.
SUMMARY

A theoretical analysis is conducted to determine the effect of wanes on the bearing capacity of timber in light of the reduction they entail in cross-sectional area compared to fully rectangular sections. The concomitant loss of bending strength is likewise evaluated. Parallel tests are run on 84 samples -51 with wanes- of large section, Scotch (Pinus sylvestris L.) and Corsican (Pinus pinaster Ait.) pine beams taken from old buildings. The bending strength, modulus of elasticity and density are found in accordance with European standard EN 408.

The mechanical properties of the specimens with and without wanes are found to be very similar, and no statistically significant differences are recorded. The effect of the decline in section may be offset by greater continuity of surface fibres and the section shape effect. One practical consequence of this finding is that (within certain limits) wanes may be disregarded when grading large section timber beams in existing structures, where this flaw is very common; this in turn would reduce the high percentage of rejected beams imposed by the present visual grading standards.

Keywords: timber, mechanical properties, defects, wanes, visual grading.

(*) Universidad Politécnica de Madrid (Madrid, España). 


\section{INTRODUCCIÓN}

Cada vez es más frecuente que la reglamentación sobre edificación obligue al mantenimiento de la estructura de madera en las obras de rehabilitación de edificios históricos. La conservación del patrimonio histórico y artístico incluye no sólo la conservación de las fachadas y la configuración arquitectónica visible, sino también la conservación de las partes de la estructura que no quedan a la vista. De este modo se conservan, también, las tecnologías originales de una manera más auténtica. Por otro lado, la normativa relacionada con la seguridad estructural obliga a la peritación de la estructura del edificio, incluyendo la estructura de madera.

El método más inmediato para la evaluación de la capacidad resistente de estructuras antiguas de madera es la aplicación de las reglas de clasificación visual, tal y como se hace para la madera aserrada nueva. La clasificación visual se realiza mediante la medición de las singularidades de la madera (o defectos de la madera) siguientes: nudos, desviación de la fibra, fendas, gemas y otros (bolsas de resina, entrecasco, madera de reacción). Los más relevantes en la resistencia de la pieza de madera son los dos primeros: nudos y desviación de la fibra. El efecto que producen en la resistencia de la madera ha sido estudiado abundantemente. El efecto de los nudos es una combinación de una pérdida local de sección junto con una desviación local de la fibra. La desviación de la fibra produce una reducción de la resistencia que puede evaluarse mediante la fórmula de Hankinson (1) que todavía se mantiene en las normas actuales de cálculo.

En el caso de las estructuras existentes, la clasificación visual es mucho más compleja que en la madera nueva. Aparte de los posibles daños que pueden presentar las piezas por los organismos biológicos, lo que sería objeto de un análisis específico, existe una clara dificultad para poder realizar la inspección visual. Muchas veces las piezas están ocultas total o parcialmente, y en el mejor de los casos siempre tienen una cara oculta. Por tanto, en la práctica no es posible realizar una inspección completa aplicando todos los criterios de la norma de clasificación.

Cuando se aplica el criterio completo de las normas de clasificación visual a la madera de estructuras existentes, el porcentaje de rechazos (piezas que no alcanzan la calidad mínima de la norma) es muy elevado. Por estas razones, algunos estudios proponen una clasificación utilizando únicamente los defectos más relevantes (2).

Las gemas constituyen uno de los defectos de aserrado contemplados por las normas de clasificación visual y consisten en la falta de arista viva en una o varias esquinas de la sección, debido al aprovechamiento del tronco

\section{INTRODUCTION}

More and more building codes call for the maintenance of timber structures in historic building rehabilitation works. Conservation of the historic-artistic heritage implies protection not only for facades and other visible architectural elements, but for concealed parts of the structure as well, to conserve the original technology more authentically. At the same time, legislation on structural safety calls for structural verification of buildings, including wood frame structures.

The most convenient way to assess the bearing capacity of old wood structures is to apply the same visual grading standards as used for newly sawn timber. Visual grading involves measuring knots, slope of grain, fissures, wanes and other defects (resin pockets, bark pockets, compression wood). The effects on timber strength of the two most relevant defects from the standpoint of strength, knots and slope of grain, have been widely studied. The effect of knots is a combination of locally reduced section and local slope of grain. Slope of grain occasions a decline in strength that can be calculated from the Hankinson formula (1), which is still in use in today's engineering standards.

Visual grading is much more complex in existing structures than in new timber. In addition to the possible damage caused by living organisms, which should be the subject of specific analysis, there are obvious obstacles to visual inspection. Members are often wholly or partially concealed and even in the best of circumstances one side is necessarily out of sight. In practice, then, a thorough inspection in which all the grading rules are applied is not feasible.

When all the requisites of visual grading standards are applied to existing timber structures, a high percentage of pieces must be rejected (for failure to meet minimum quality criteria). For this reason some authors propose a grading system for existing structures based on only the most relevant flaws (2).

Wanes, which are sawing defects consisting in the lack of sharp corners to optimize the amount of timber extracted from the trunk, are among the flaws included in visual grading standards. While they do not affect 
durante el proceso de aserrado. Las gemas son defectos de aserrado que no afectan a las cualidades resistentes de la madera, sino que sólo producen una pérdida de sección y de simetría.

El defecto de las gemas aparece con gran frecuencia en las piezas de madera en estructuras existentes, sobre todo en estructuras que no quedan a la vista $y$, por tanto, no existe un requisito estético para la presencia de las aristas vivas. Si se exigen las limitaciones del tamaño de las gemas habituales en las normas de clasificación visual, el porcentaje de rechazos es muy elevado, como se verá posteriormente.

La limitación del tamaño de las gemas en las normas de clasificación visual se debe principalmente a razones de orden constructivo, como la conveniencia de una superficie plana para permitir el clavado o encolado o para el apoyo de las piezas, así como la necesidad de contar con la sección completa de la pieza en la zona donde se realizan las uniones. La pérdida de capacidad resistente de la pieza resulta secundaria frente a las razones constructivas.

De esta manera, el efecto de las gemas en la resistencia de la pieza es, en el peor de los casos, equivalente a una pérdida de sección y, por tanto, de capacidad portante. En realidad, su efecto será todavía menos grave debido al hecho de que la superficie de las gemas no presenta un corte de las fibras, como ocurre en las aristas vivas, y esto supone menor pérdida de resistencia. La sección transversal de una pieza con gemas importantes deja de ser rectangular y puede aparecer un efecto de la forma de la sección. Este factor de forma fue estudiado por primera vez por Newlin y Trayer (3) y para el caso de la sección circular la capacidad de resistencia a flexión resulta 1,18 veces superior a la obtenida en sección rectangular. Una sección circular y una cuadrada con el mismo área presentan la misma capacidad portante en flexión.

En este trabajo se pretende analizar teóricamente el efecto de las gemas en la capacidad resistente a flexión en vigas de madera y contrastarlo experimentalmente mediante el ensayo de piezas con gemas procedentes de estructuras existentes. La finalidad es apoyar la propuesta de una clasificación menos exigente en la limitación del tamaño de las gemas para la evaluación de vigas de forjado de estructuras existentes.

Las gemas constituyen un defecto, entre otros, que disminuye el valor de la madera tras el aserrado. Por este motivo, existen numerosos trabajos de investigación que se orientan a la optimización del tronzado y despiece de la madera en rollo mediante sistemas automáticos que detectan las singularidades como los nudos y gemas (4). Algunos estudios sobre la devaluación en el mercado de inherent timber strength, they do occasion locally smaller sections and asymmetries.

Wanes are very common in existing structures, particularly in non-exposed members where there is no aesthetic need for sharp arris. The limitations on wane size normally specified in visual grading standards lead to a high percentage of rejected pieces, as discussed below.

These limitations on wane size are primarily related to construction requirements, such as the need for a flat surface where beam supports can be nailed or glued, or for an intact cross-section at beam joints. The decline in bearing capacity is secondary to such considerations.

In other words, the effect of wanes on member strength is to reduce the cross-sectional area and with it total bearing capacity. The net effect is even less significant because timber fibre is not interrupted at wane surfaces as it is in sharp arris and this partially offsets the strength loss. Moreover, since the cross-section of pieces with substantial wanes is not rectangular, they may be impacted by the section shape effect. This factor was first studied by Newlin and Trayer (3), who reported that bending strength is 1.18 times greater in circular than in rectangular sections. This means that circular and square sections with the same area exhibit the same bending strength.

The present study consists in verifying the results of a theoretical analysis of the effect of wanes on timber beam bending strength against the experimental data obtained by testing wane-containing members removed from existing structures. The ultimate aim is to support a proposal for less demanding limitations on wane size in grading systems used to evaluate beams in existing structures.

Wanes are one of the several flaws that reduce the value of timber after sawing. For this reason, any number of research papers has been published on ways to optimize trunk cutting and sawing with automatic systems that detect flaws such as knots and wanes (4). Certain studies on the market devaluation of timber due to wanes focus on specific products such as pallets (5), where they 
la madera por efecto de las gemas están enfocados a productos concretos como los pallets, utilizando técnicas de ultrasonidos para su medición (5) o la madera tratada (6). Estos estudios se basan en el empleo de técnicas láser y analizadores de imagen tridimensional (7) o infrarrojos orientados a la detección de nudos (8).

Otro enfoque bajo el que se pueden estudiar las singularidades de la madera es en su relación con los defectos de deformaciones (curvatura de cara y de canto, alabeo y atejadura). En esta línea existen muchos trabajos de investigación que analizan la influencia de las singularidades de crecimiento (madera de compresión, madera juvenil, gemas) en la deformación de la pieza tras el secado. Las gemas se relacionan con el defecto de la curvatura de canto, en algunos trabajos (9), y en otros prácticamente ni se mencionan (10).

Otros estudios analizan la influencia de los defectos en la evaluación no destructiva de algunas maderas, en particular como el fresno (11), relacionando parámetros como nudos, desviación de la fibra, presencia de duramen o espesor de los anillos con otros parámetros acústicos. También en la madera de abeto blanco se ha analizado la influencia de los nudos y la desviación de la fibra junto a los efectos del secado y la presencia de madera juvenil en las propiedades mecánicas de la madera (12). En estos casos, tampoco se hace mención a las gemas.

Por otro lado, es también abundante el número de trabajos de investigación sobre la influencia de los defectos en las propiedades mecánicas de la madera. En este sentido, puede citarse el estudio de la influencia de los defectos tales como los nudos, desviación de la fibra, incluso la influencia del secado en las propiedades mecánicas de la madera aserrada de la especie white spruce, sin que se cite el efecto de las gemas (13). El tamaño de los nudos y su posición es, junto con la desviación de la fibra, el defecto de mayor relevancia en la resistencia de las piezas de madera. Sin embargo, otros defectos como las fendas y las gemas cuentan con muchos menos trabajos de investigación sobre su influencia en las propiedades mecánicas.

Otros estudios más relacionados con los efectos de las gemas son los llevados a cabo sobre rollizo de pequeño diámetro (14). Se han realizado estudios basándose en factores de forma para comparar la eficacia estructural a flexión de rollizos de pequeño diámetro con la madera escuadrada, obteniéndose valores de resistencia del orden de 3 a 4 veces superior en el rollizo simplemente descortezado respecto a la pieza de sección rectangular, cuyas dimensiones quedan inscritas en el diámetro del rollizo. Además de obtener resistencias más altas, se obtienen resultados con una dispersión are measured with ultrasound techniques, or treated wood (6). These surveys are based on the use of laser techniques and three-dimensional imaging analysis (7) or infrared knot detection (8).

Another approach that may be adopted for studying wood flaws is to relate them to bow, spring, twist or cup warping. Much research has been conducted in this regard to analyze the effect of growth flaws (compression wood, juvenile wood, wanes) on warping after drying. While wanes are associated with spring in some papers (9), in others they are barely mentioned (10).

Some authors have analyzed the effect of flaws on the non-destructive evaluation of certain specific types of wood such as ash (11), relating knots, slope of grain, presence of heartwood or thickness of rings to acoustic parameters. Yet another study, in this case on the impact of knots and slope of grain in Whitewood, together with the effects of drying and the presence of juvenile wood on timber strength (12), makes no reference to wanes either.

In another vein, the literature abounds with reports of research on the effects of flaws on timber strength. In this regard, reference may be made to a survey on the effect of knots, slope of grain and even drying on sawn timber strength in White spruce, in which nothing is said about wanes (13). Knot size and position, along with slope of grain, are the flaws most relevant to timber strength. Much less research has been published, however, on the effect of flaws such as fissures and wanes on mechanical properties.

Studies on small diameter round members (14) are more closely related to the effect of wanes. Shape factor studies conducted to compare the bending strength of small diameter round to sawn timber have found strength values on the order of three to four times higher in simply debarked logs than in rectangular section pieces of dimensions fitting within their diameter. In addition to greater strength values, the results for the round members exhibited perceptibly narrower scatter, yielding higher characteristic values and therefore higher performance from the standpoint of structural engineering. Some of 
sensiblemente menor, lo que repercute en la obtención de valores característicos más altos y, por tanto, mayor eficacia en el cálculo estructural. Alguna de las causas de estas diferencias, más allá del mero hecho de que la sección es ligeramente mayor, se deben a que en el rollizo las fibras de la madera no se ven interrumpidas en el entorno de los nudos, cosa que sí ocurre en la madera aserrada dando lugar a concentraciones locales de tensiones que, normalmente, son las que desencadenan la rotura.

\section{MATERIALES Y MÉTODOS}

\subsection{Descripción de la muestra de ensayo}

El material utilizado fue obtenido de varios edificios antiguos que habían sido desmontados parcialmente durante las obras de rehabilitación (2). Las piezas analizadas en este estudio eran de dos especies: 52 piezas de pino silvestre (Pinus sylvestris L.) y 32 piezas de pino pinaster (Pinus pinaster Ait.). Las características generales y la procedencia de cada serie de piezas se muestran en la Tabla 1.

Las dimensiones de las gemas a lo largo de la pieza se midieron en secciones distanciadas a $30 \mathrm{~cm}$, Figura 1 . En este registro también se incluían las restantes singularidades contempladas en las normas de clasificación tales como el tamaño y la posición de los nudos, fendas, gemas y desviación de la fibra. these differences are due, more than to the slightly larger section, to the fact that in round members wood fibres are not interrupted around the knots as they are in sawn timber. Such interruptions are known to give rise to the local concentration of stress that normally triggers failure.

\section{MATERIALS AND METHODS}

\subsection{Test samples}

The material used was obtained from several old buildings that had been partially dismantled for rehabilitation (2). The pieces analyzed in this study were made from two pine species: 52 were Scotch (Pinus sylvestris L.) and 32 Corsican (Pinus pinaster Ait.) pine. The general characteristics and origin of each series of pieces are given in Table 1.

Wane dimensions were measured at $30-\mathrm{cm}$ intervals along the length of the piece (Figure 1). A record was also made of the other parameters addressed in grading standards, such as the size and position of knots, fissures, wanes and slope of grain.

Tabla 1 / Table 1

Material analizado

Sample material

\begin{tabular}{|c|c|c|c|c|}
\hline Serie & $\begin{array}{l}\text { Número y especie } \\
\text { Number of pieces } \\
\text { and species }\end{array}$ & $\begin{array}{l}\text { Sección b x h }(\mathbf{m m}) \\
\text { Section }\end{array}$ & $\begin{array}{l}\text { Longitud }(\mathbf{m}) \\
\text { Length }(m)\end{array}$ & $\begin{array}{l}\text { Procedencia } \\
\text { Source }\end{array}$ \\
\hline A & $\begin{array}{l}18 \text { viguetas }(13 s+5 p) \\
18 \text { joists }(13 s+5 p)\end{array}$ & $\begin{array}{l}130 \times 180 \\
130 \times 180\end{array}$ & $\begin{array}{l}4 \text { a } 5 \\
4 \text { to } 5\end{array}$ & $\begin{array}{l}\text { Edif. urbano. Madrid, } 1861 \\
\text { Urban building. Madrid, } 1861\end{array}$ \\
\hline B & $\begin{array}{l}12 \text { pares }(12 p) \\
12 \text { rafters }(12 p)\end{array}$ & $\begin{array}{l}120 \times 160 \\
120 \times 160\end{array}$ & $\begin{array}{l}4 \\
4\end{array}$ & $\begin{array}{l}\text { Edif. urbano. Vallecas, Madrid, ca. } 1900 \\
\text { Urban building. Vallecas, Madrid, ca. } 1900\end{array}$ \\
\hline C & $\begin{array}{l}3 \text { viguetas (3s) } \\
3 \text { joists (3s) }\end{array}$ & $\begin{array}{l}96-129 \times 166 \\
96-129 \times 166\end{array}$ & $\begin{array}{l}4 \\
4\end{array}$ & $\begin{array}{l}\text { Edif. urbano. Madrid, } 1836 \\
\text { Urban building. Madrid, } 1836\end{array}$ \\
\hline D & $\left|\begin{array}{l}25 \text { viguetas y pares }(25 \mathrm{~s}) \\
25 \text { joists and rafters }(25 \mathrm{~s})\end{array}\right|$ & $\begin{array}{l}140 \times 195 \\
140 \times 195\end{array}$ & $\begin{array}{l}4,5 \text { a } 5 \\
4.5 \text { to } 5\end{array}$ & $\begin{array}{c}\text { Edif. urbano. Aranjuez, Madrid, finales s. XVIII } \\
\text { Urban building. Aranjuez, Madrid, } \\
\text { late } 18^{\text {th }} \mathrm{C} .\end{array}$ \\
\hline $\mathrm{E}$ & $\begin{array}{c}19 \text { piezas de cerchas } \\
(6 s+13 p) \\
19 \text { truss pieces }(6 s+13 p)\end{array}$ & $\begin{array}{l}98-115 \times 185-209 \\
98-115 \times 185-209 \\
\end{array}$ & $\begin{array}{l}2,8 \text { a } 3,5 \\
2.8 \text { to } 3.5\end{array}$ & $\begin{array}{l}\text { Edif. industrial. Valladolid, } 1951 \\
\text { Industrial building. Valladolid, } 1951\end{array}$ \\
\hline $\mathrm{F}$ & $\begin{array}{c}7 \text { viguetas }(5 s+2 p) \\
7 \text { joists }(5 s+2 p)\end{array}$ & $\begin{array}{l}90-190 \times 195-220 \\
90-190 \times 195-220\end{array}$ & $\begin{array}{l}4 \text { a } 4,5 \\
4 \text { to } 4.5\end{array}$ & $\begin{array}{l}\text { Edif. urbano. León, finales s. XIX } \\
\text { Urban building. León, late } 19^{\text {th }} C \text {. }\end{array}$ \\
\hline
\end{tabular}

s: pino silvestre / Scotch pine; p: pino pinaster / Corsican pine. 
Las piezas fueron clasificadas de acuerdo con la norma UNE 56544 en las dos clases que define (ME-1 y ME-2). La calidad se asignó a la zona de la sección de rotura después del ensayo mecánico. En la Tabla 2 se muestra la asignación de piezas a cada calidad de la norma, así como la asignación de calidad debida al parámetro de las gemas.

\subsection{Medición de las gemas}

\subsubsection{Evaluación de las gemas en las normas} de clasificación visual

Normalmente, las piezas de madera utilizadas en estructuras antiguas eran de gran escuadría y de secciones enterizas, en las que el corazón se encuentra sensiblemente centrado. En este tipo de piezas, las gemas se manifiestan en una, dos o cuatro aristas. Por razones de simetría, son excepcionales las secciones en las que se manifiestan en dos aristas diagonalmente opuestas y muy poco frecuentes en tres. Por la misma razón, cuando hay dos gemas, se suelen presentar asociadas al mismo lado, Figura 2.
The pieces were graded in accordance with the provisions of standard UNE 56544 into the two grades specified ME-1 and ME-2. The failure zone was rated for quality on the grounds of the mechanical test. Table 2 shows the results of overall and wane-only grading of the sample pieces.

\subsection{Wane measurement}

\subsubsection{Wane evaluation in visual grading standards}

The timber members used in existing structures normally have very large, solid sections whose pith is perceptibly centred. In this type of pieces, wanes may be found on one, two or four arris. For reasons of symmetry they are highly unusual on two diagonally opposed arris and very uncommon on three. For the same reason, when there are two wanes, they are generally on the same side of the piece (Figure 2).

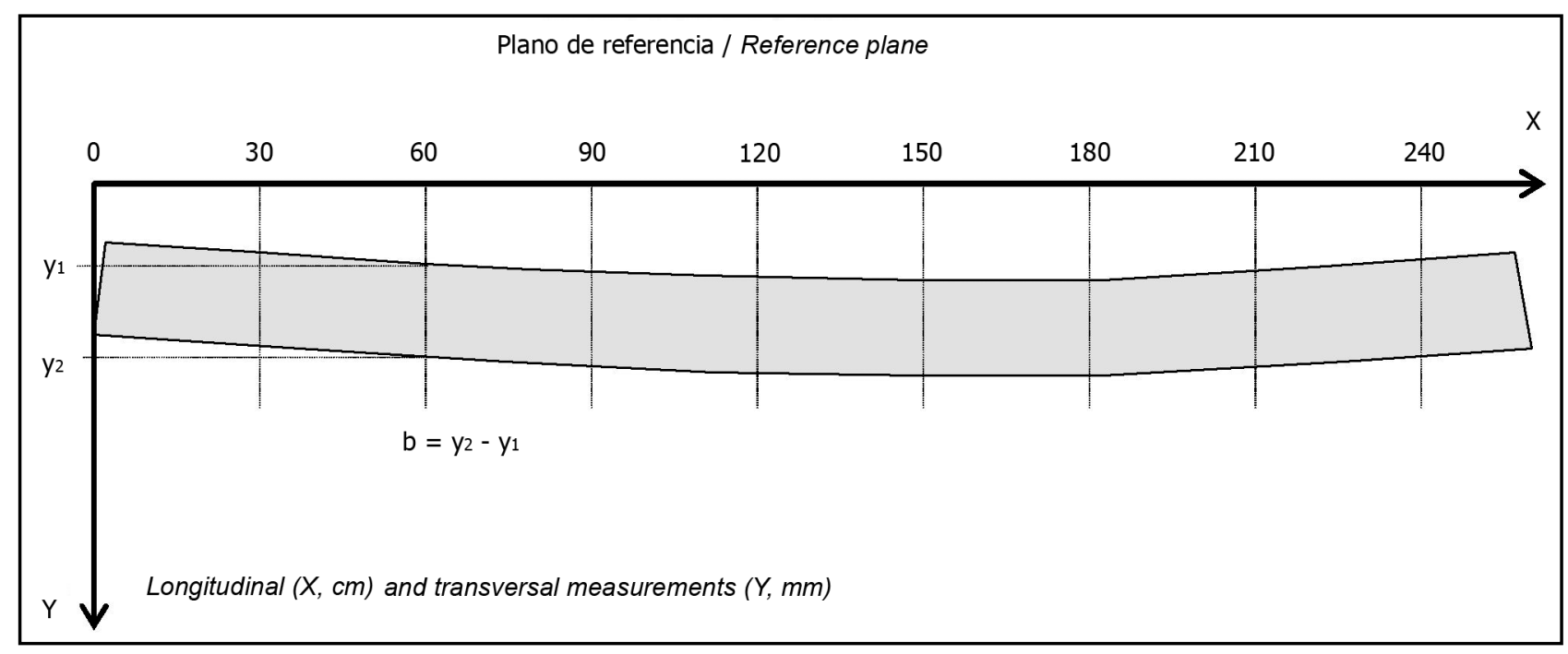

Figura 1. Registro de las dimensiones y las singularidades de clasificación. Figure 1. Visual grading: record of dimensions and flaws.

Tabla 2 / Table 2

Resultados de la clasificación visual de acuerdo con la norma UNE 56544 Results of visual grading pursuant to standard UNE 56544

\begin{tabular}{|l|c|c|c|c|c|}
\hline & & ME-1 & ME-2 & $\begin{array}{c}\text { Rechazos } \\
\text { Rejected }\end{array}$ & Total \\
\hline Criterio completo / All criteria & No de piezas / No. of pieces & 9 & 37 & 38 & 84 \\
\hline & Rendimiento (\%) / Performance & 11 & 44 & 45 & 100 \\
\hline Sólo por gemas / Wanes only & No de piezas / No. of pieces & 43 & 9 & 32 & 84 \\
\hline & Rendimiento (\%) / Performance & 51 & 11 & 38 & 100 \\
\hline
\end{tabular}


El procedimiento para la evaluación de las gemas varía ligeramente entre las diferentes normas de clasificación. Como ejemplo se pueden citar los procedimientos expresados en la norma UNE 56544 (15), la norma DIN 4074-1 (16) y en la norma EN 14081-1 (17).

\section{Norma UNE 56544}

Esta norma mide la longitud de la gema $\left(L_{1}\right)$ y su dimensión en el canto (n) y en la cara de la pieza (m), Figura 3.

La evaluación de la gema se realiza a través de la relación entre la dimensión sin gemas $\left(\mathrm{h}_{1}=\mathrm{h}-\sum \mathrm{m}_{\mathrm{i}} ; \mathrm{b}_{1}=\mathrm{b}\right.$ - $\sum \mathrm{n}_{\mathrm{i}}$ ) y la dimensión del rectángulo en que se inscribe la sección y en longitud respecto a la longitud total de la pieza, según las siguientes expresiones [1]:
The procedure for evaluating wanes varies slightly from one grading standard to another. By way of example, the procedures laid down in Spanish standard UNE 56544 (15), German standard DIN 4074-1 (16) and European standard EN 14018-1 (17) are compared below.

\section{UNE standard 56544}

The method laid down in this standard calls for measuring the length of the wane $\left(L_{1}\right)$ and its dimensions on the edge $(n)$ and face $(m)$ of the piece (Figure 3).

The wane is evaluated in terms of the ratio between the waneless dimension $\left(h_{1}=h-\sum m_{i} ; b_{1}=b-\sum n_{i}\right)$ and the dimension of the rectangle into which the section fits; and length-wise in terms of the ratio between its length and the total length of the piece, as in the following expressions [1]:

$$
g=\max \left(\frac{h-h_{1}}{h}, \frac{b-b_{1}}{b}, \frac{b-b_{2}}{b}\right) ; \frac{L_{1}}{L}
$$

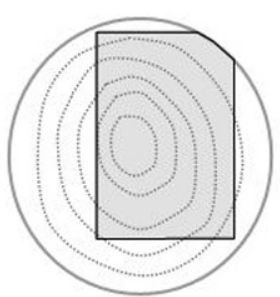

1 arista / 1 wane

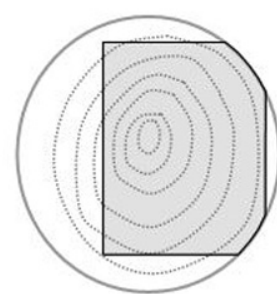

2 aristas (cara) / 2 wanes (face)

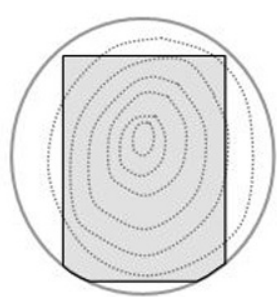

2 aristas (canto) / 2 wanes (edge)

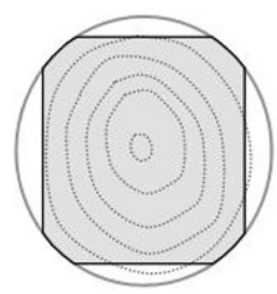

4 aristas / 4 wanes

Figura 2. Posición de las gemas.

Figure 2. Wane location on sample.
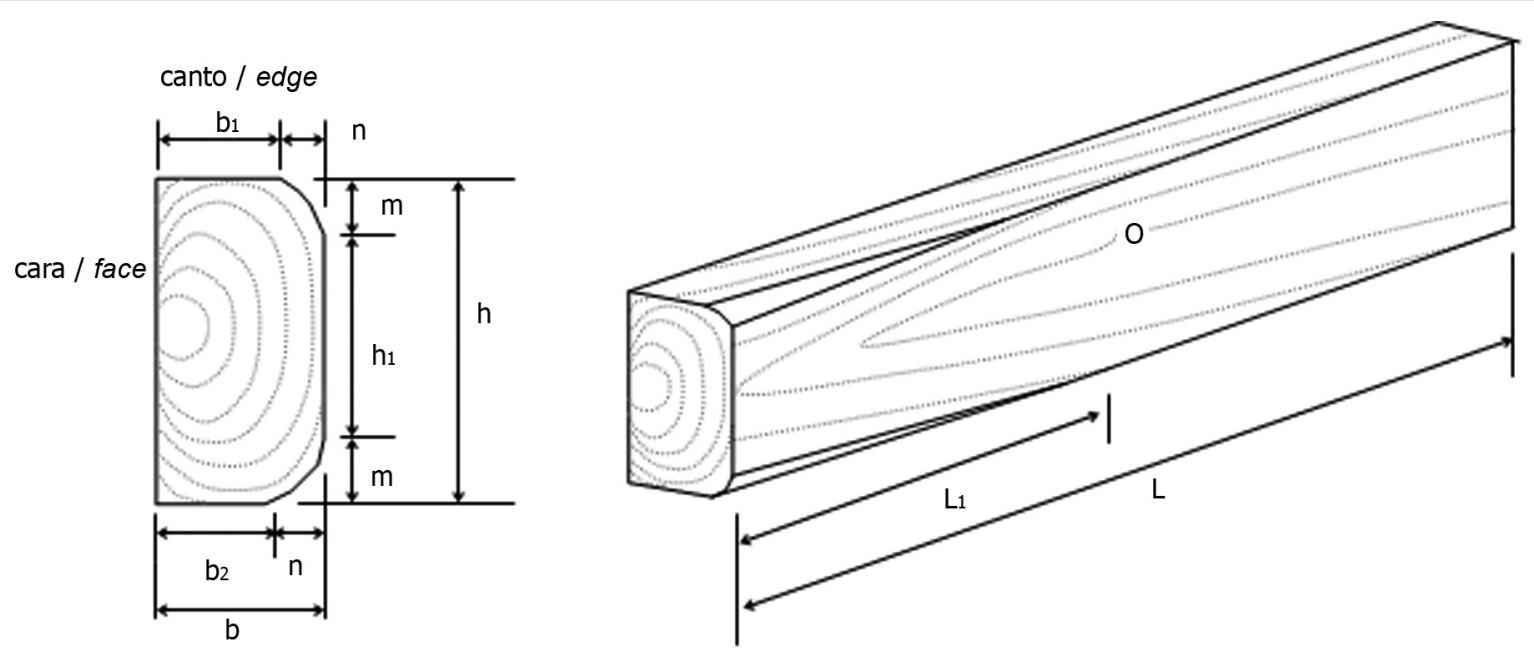

Figura 3. Medición de gemas según norma UNE 56544.

Figure 3. Wane measurement as per Spanish standard UNE 56544. 
Las especificaciones de la norma UNE 56544 para cada calidad (ME-1 y ME-2) son las siguientes [2-3]:
The UNE 56544 specifications for qualities ME-1 and ME-2 are [2-3]:
$\begin{array}{ll}M E-1 & g \leq 1 / 4 ; L_{1} / L \leq 1 / 4 . \\ M E-2 & g \leq 1 / 3 ; L_{1} / L \leq 1 / 3 .\end{array}$
Norma DIN 4074-1

Esta norma utiliza el mismo procedimiento que la norma UNE 56544; en realidad la norma UNE adoptó el procedimiento que ya proponía la norma DIN con anterioridad. La única diferencia consiste en que la norma DIN 40741 no limita la longitud de la gema. Las calidades definidas en la norma son tres: S13, S10 y S7, con las especificaciones siguientes para las gemas [4-5]:

\section{DIN standard 4074-1}

This standard describes the same method as UNE 56544; in fact, the Spanish norm adopted the procedure previously laid down in the DIN standard. The only difference is that DIN 4074-1 does not limit the wane length and it defines three qualities: S13, S10 and S7, with the following wane specifications [4-5]:

$$
\begin{aligned}
& \mathrm{S} 13, \mathrm{~g} \leq 1 / 4 \\
& \mathrm{~S} 10 \text { y } \mathrm{S} 7, \mathrm{~g} \leq 1 / 3
\end{aligned}
$$

\section{Norma EN 14081-1}

Esta norma especifica los requisitos generales de la clasificación visual de la madera estructural con el fin de servir de guía para la redacción de normas nacionales de clasificación. Establece que la máxima gema permitida no reduzca la dimensión del canto o de la cara a menos de 2/3 de las dimensiones originales de la sección (Figura 4).

Recomienda la limitación de las gemas por razones constructivas. Indica que puede ser especialmente rechazable cuando se utilizan placas metálicas dentadas, conectores o en el caso de una compresión perpendicular a la fibra. La especificación que propone esta norma coincide con la menor exigencia de las normas antes citadas.

\subsubsection{Pérdida de sección por efecto de las gemas}

En la peritación de una estructura de madera es práctica habitual tomar las dimensiones de la sección como la anchura y la altura del rectángulo en el que se inscribe la sección real con sus posibles gemas e irregularidades (bxh). A la sección así definida la denominaremos en adelante sección nominal. Por otro lado, éste es el procedimiento que siguen las normas de clasificación.

Una posible opción en el proceso de clasificación visual para no tener que considerar las gemas como un defecto que rebaje la calidad de la pieza es introducir un factor de penalización de la resistencia de la pieza que sea equivalente a la pérdida de capacidad portante de la sección (factor de gema $\mathrm{k}_{\mathrm{w}}$ ). De esta manera, la pieza se clasificaría sin considerar la gema y, posteriormente,

\section{EN standard 14018-1}

This standard lays down the general requirements for the visual grading of structural timber that serve as a guide for national grading standards. It provides that the largest wane allowed may not reduce the edge or face to less than 2/3 of the dimensions of the original section (Figure 4).

It recommends limiting wanes for construction reasons. It specifies that rejection is particularly pertinent when toothed steel plates or connectors are to be used, or in the presence of compression stress perpendicular to the grain. The specifications proposed in this standard concur with the least demanding requirements laid down in the preceding two.

\subsubsection{Wanes and loss of section}

Further to standard practice in timber structure appraisal, section dimensions are taken to be the width and height of the rectangle into which the actual section, with its wanes and irregularities, fits (bxh). That section is referred to here as the nominal section. This is, moreover, the procedure set out in grading standards.

A possible alternative, in the visual grading process, to regarding wanes to be a defect that lowers piece quality is to introduce a strength penalization factor in the piece equivalent to the sectional loss of bearing capacity (wane factor $k_{w}$ ). The wane could thereby be disregarded when grading the piece; subsequently the strength corresponding to the strength class assigned 
la resistencia deducida por la clase resistente asignada se reduciría multiplicando por este factor de gema.

En este apartado se expone la determinación de la pérdida de resistencia a flexión en los casos habituales de gemas en uno, dos o cuatro aristas de la sección. Para su obtención se aceptan las simplificaciones siguientes: se considera que las gemas presentes en una sección son simétricas respecto a los ejes " $y$ " y " $z$ "; y se considera que la superficie curva de la gema es un plano. Para cada caso de gemas se obtiene un "factor de gema" que permite estimar la pérdida de resistencia a flexión de la sección. Se ha considerado que la flexión se produce respecto al eje fuerte de la sección (eje $z$ en las figuras).

\section{Gemas en las cuatro aristas}

Éste es el caso de más sencilla solución, ya que el centro de gravedad de la sección transversal ocupa la misma posición que en la sección completa, Figura 5.

La pérdida de momento de inercia $\left(\Delta \mathrm{I}_{\mathrm{z}}\right)$ se obtiene como la relación entre el momento de inercia de la sección con gemas $\left(\mathrm{I}_{\mathrm{zw}}\right)$ y la inercia completa $\left(\mathrm{I}_{\mathrm{z}}\right)$. Análogamente se puede deducir la pérdida de capacidad resistente a flexión $\left(\Delta W_{z}\right)$ como la relación entre el módulo resistente de la sección con gemas $\left(W_{\mathrm{zW}}\right)$ y el módulo de la sección completa $\left(\mathrm{W}_{\mathrm{z}}\right)[6]$ : would be reduced by multiplying the strength value times the wane factor.

This section discusses the determination of the loss of bending strength in the usual cases of wanes on 1, 2 or 4 arris. The following simplifications were adopted: the wanes present in a section were assumed to be symmetrical with respect to axes " $y$ " and " $z$ "; and the curved surface of the wane was considered to be flat. A "wane factor" was obtained for each case, from which the loss of sectional bending strength was estimated. Bending was assumed to occur along the strong axis of the section (axis $z$ in the figures).

\section{Wanes on all four corners}

This is the simplest case to solve, since the centre of gravity of the cross-section in the actual piece occupies the same position as in the full section (Figure 5).

The loss of the second moment of area $\left(\Delta I_{z}\right)$ was obtained as the ratio between the second moment of area of the section with wanes $\left(I_{z w}\right)$ and full inertia $\left(I_{z}\right)$. Analogously, the loss of bending strength $\left(\Delta W_{z}\right)$ can be deduced as the ratio of the section modulus with wanes $\left(W_{z w}\right)$ to the section modulus of the full section $\left(W_{z}\right)[6]$ :

$$
\Delta I_{z}=\frac{I_{z w}}{I_{z}} ; \Delta W_{z}=\frac{\frac{I_{z w}}{h / 2}}{\frac{I_{z}}{h / 2}}=\Delta I_{z}
$$

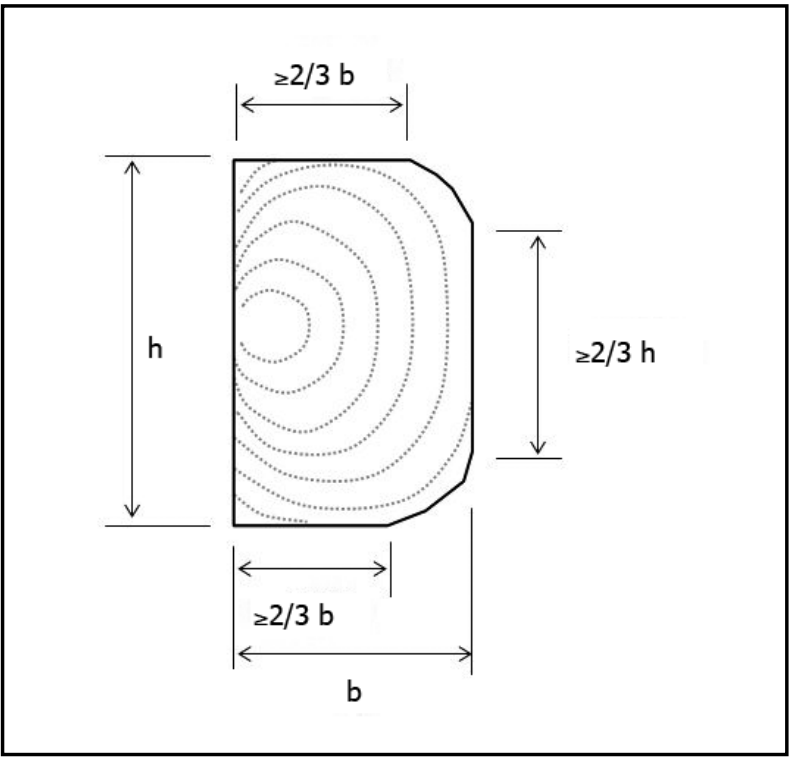

Figura 4. Recomendación de gema máxima en la norma EN 14081-1.

Figure 4. Maximum wane size recommendation in European standard EN 14081-1.

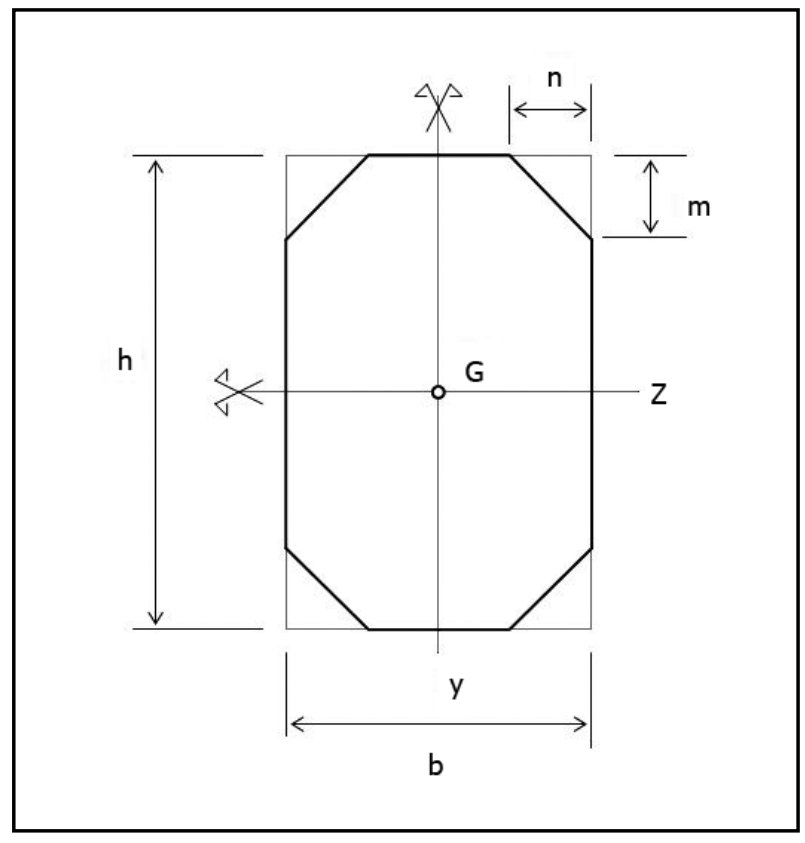

Figura 5. Gemas en cuatro aristas. Figure 5. Wanes on four corners. 
Ambas pérdidas de inercia y módulo resistente son iguales. En la figura 6 se recogen los resultados para varias relaciones de dimensiones de la gema expresadas sobre las dimensiones del canto y de la cara ( $\mathrm{n} / \mathrm{b}$ y $\mathrm{m} / \mathrm{h}$ ).

\section{Gemas en dos aristas del canto}

En este caso el centro de gravedad de la sección con gemas se encuentra desplazado hacia el lado contrario de las aristas en la que se encuentran las gemas. Los ejes principales de la sección se mantienen paralelos a los de la sección completa, Figura 7.

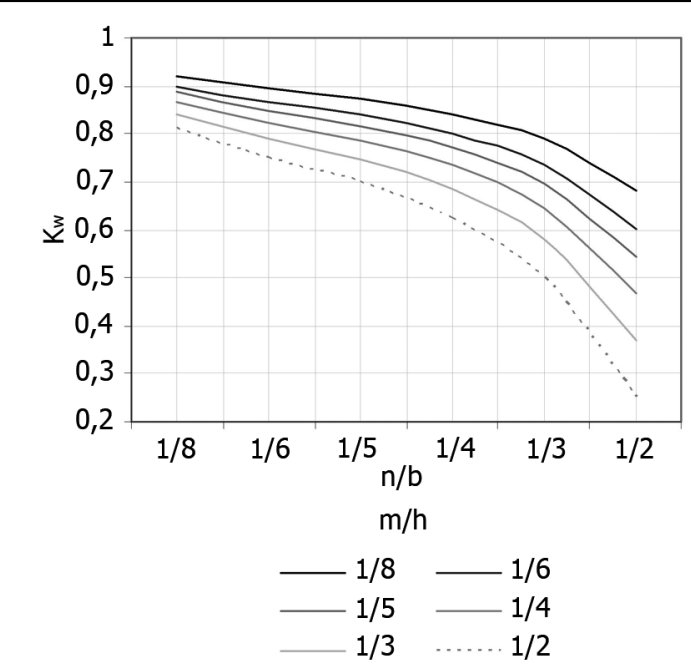

Figura 6. Reducción del módulo resistente para cuatro gemas. Figure 6. Decline in bending strength of pieces with four wanes.

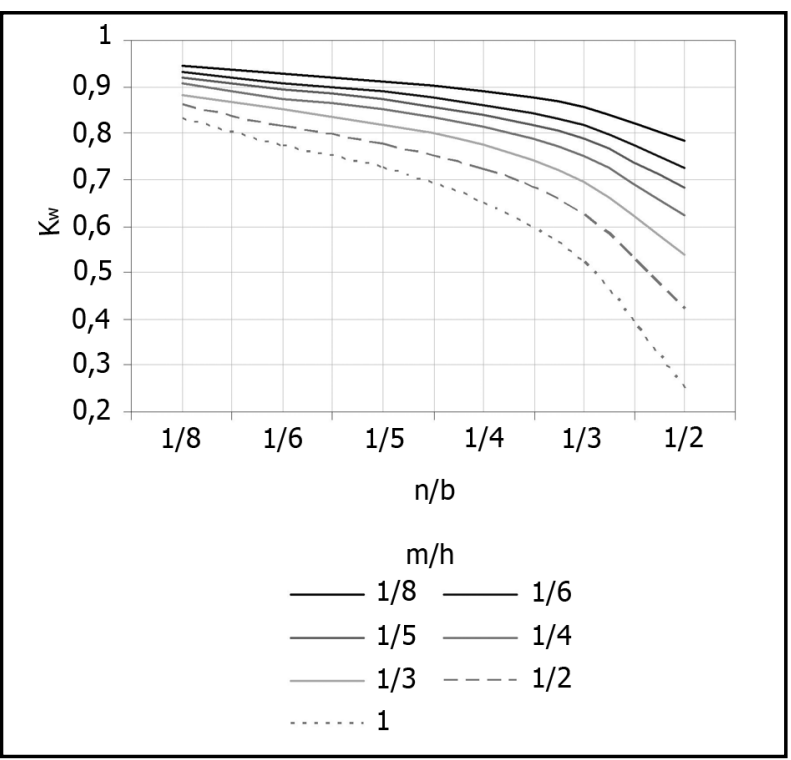

Figura 8. Reducción del módulo resistente para gemas en dos aristas del canto.

Figure 8. Decline in bending strength of pieces with two wanes on the edge.
In this case, second moment of area and section modulus (bending load capacity) losses are equal. Figure 6 shows the results for several ratios of wane dimensions to edge and face dimensions ( $n / b$ and $m / h$ ).

\section{Two wanes on an edge}

In this case the centre of gravity of the section with wanes shifts toward the side opposite the one containing the wanes. The main axes of this cross- section are parallel to the axes of the full section, as shown in Figure 7.

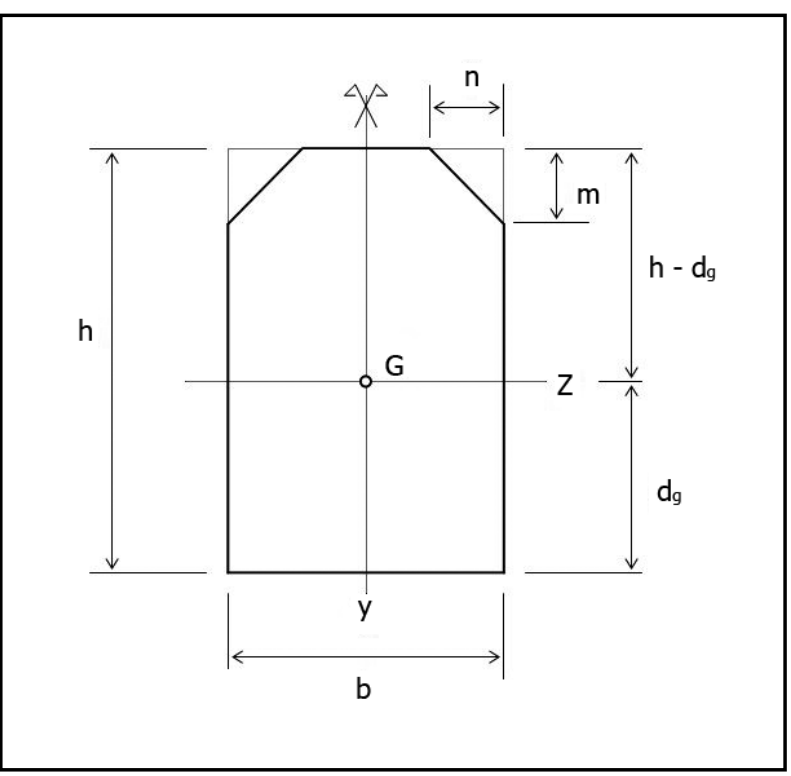

Figura 7. Gemas en dos aristas de un canto. Figure 7. Two wanes on the edge.

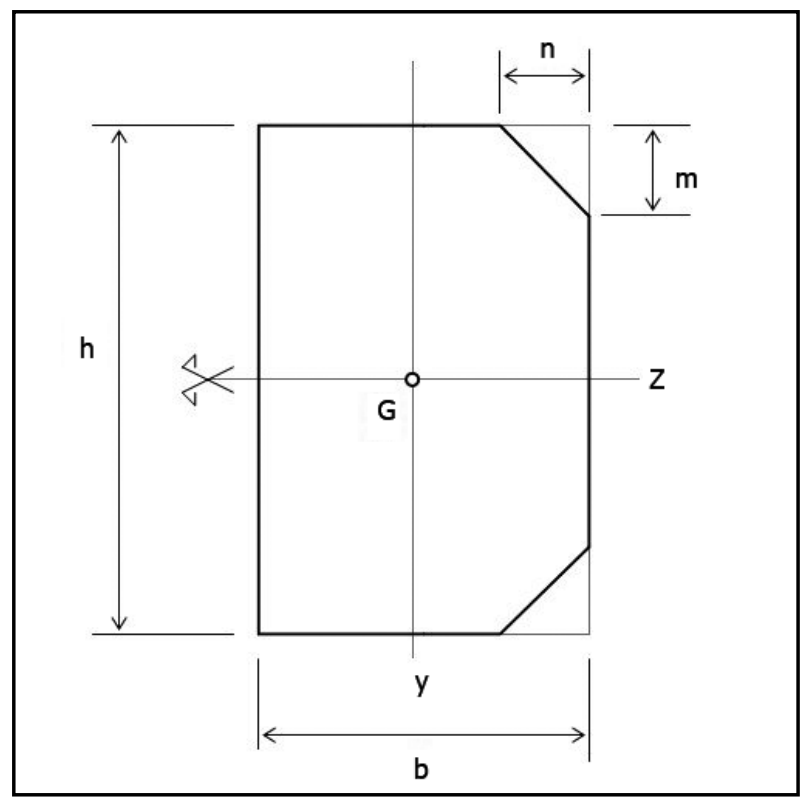

Figura 9. Gema en dos aristas de una cara. Figure 9. Two wanes on a face. 
Las variaciones del momento de inercia y del módulo resistente son las siguientes [7]:
The variations in the second moment of inertia and bending strength are as follows [7]:

$$
\Delta I_{z}=\frac{I_{z w}}{I_{z}} ; \Delta W_{z}=\frac{W_{z w}}{W_{z}} ; W_{z g}=\frac{I_{z w}}{h-d_{g}}
$$

En este caso, la pérdida de módulo resistente es mayor que la del momento de inercia. Los resultados se recogen en la Figura 8.

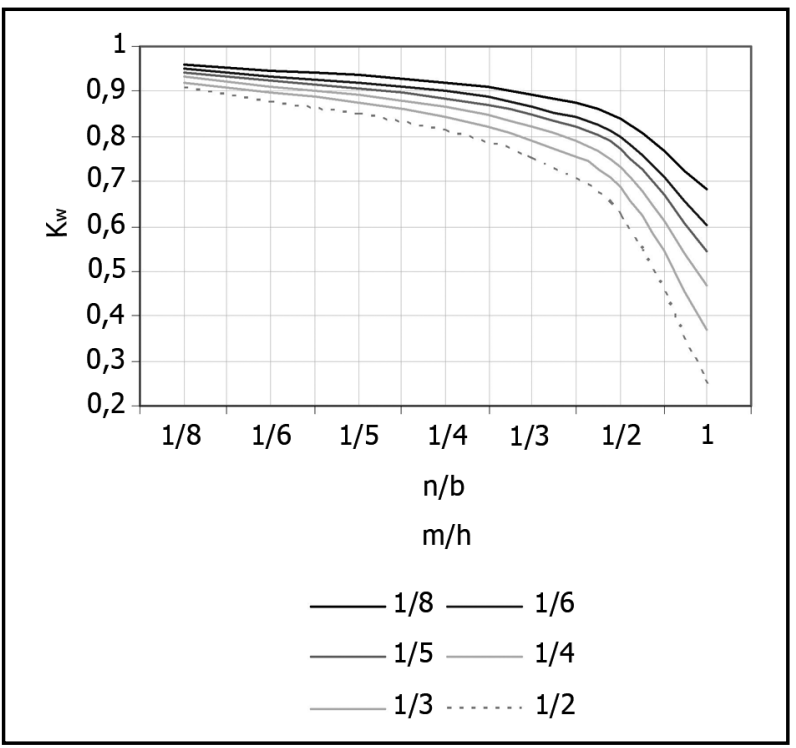

Figura 10. Reducción del módulo resistente para gemas en dos aristas de una cara.

Figure 10. Decline in bending strength of pieces with two wanes on a face.
In this case, strength loss is greater than the loss of second moment of area. The results are depicted in Figure 8.

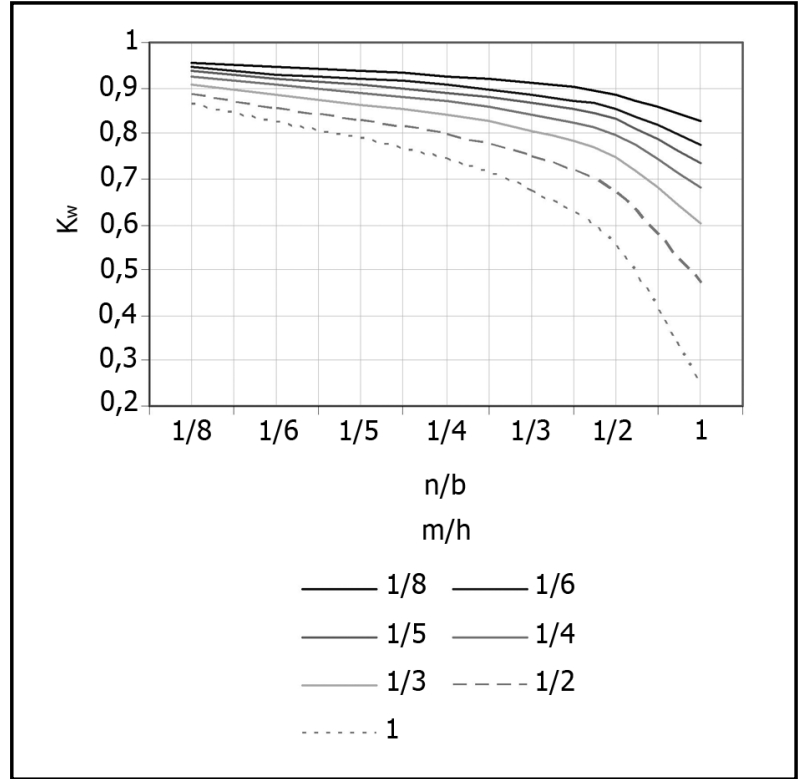

Figura 12. Reducción de la resistencia frente a cargas verticales para una gema en una arista.

Figure 12. Decline in vertical loading strength in pieces with one wane.
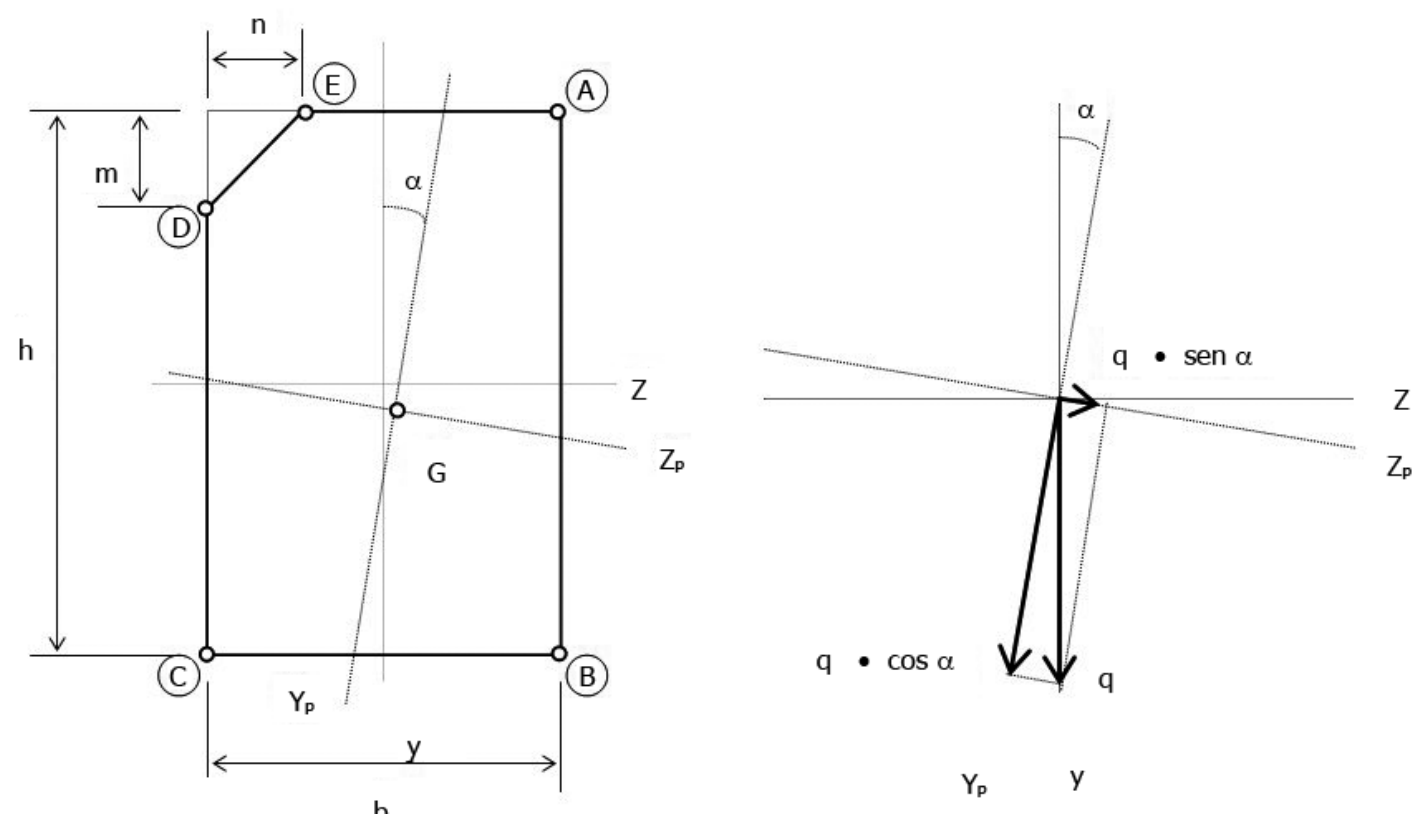

Figura 11. Gema en una arista.

Figure 11. One wane. 
Gemas en dos aristas de una cara

Se trata de un caso similar al anterior pero con la particularidad de que la pérdida de inercia y módulo resistente son iguales, ya que el eje principal " $z$ " mantiene su posición por simetría, Figura 9. Los resultados se recogen en la Figura 10.

Gema en una arista

Éste es el caso más complejo porque los ejes principales de la sección con gema no son paralelos a los de la sección completa. El centro de gravedad se desplaza alejándose de la gema y los ejes principales giran un ángulo, $\alpha$, que es función del tamaño de la gema, Figura 11.

La pérdida de capacidad resistente puede determinarse por el procedimiento que se expone a continuación. El momento flector " $\mathrm{M}_{\mathrm{z}}$ " originado por la carga " $\mathrm{q}$ " se descompone según las dos direcciones principales [8]:

$$
M_{y p}=M_{z} \cdot \operatorname{sen} \alpha ; M_{z p}=M_{z} \cdot \cos \alpha
$$

En un punto "P" de la sección de la pieza, con coordenadas $\left(y_{p p}, z_{p p}\right)$ respecto a los ejes principales de la sección, se obtienen las tensiones [9]:

$$
\sigma_{m, y p}=\frac{M_{y p}}{I_{y p}} \cdot z_{p p} ; \sigma_{m, z p}=\frac{M_{z p}}{I_{z p}} \cdot y_{p p}
$$

La tensión resultante será la suma de ambas [10]:

The resulting stress is the sum of the two [10]:

$$
\sigma_{m, w}=M_{z} \cdot\left(\frac{\operatorname{sen} \alpha}{I_{y p}} \cdot z_{p p}+\frac{\cos \alpha}{I_{z p}} \cdot y_{p p}\right)
$$

De esta manera se obtienen las tensiones para los cinco puntos que constituyen los vértices de la sección con gema $(A, B, C, D$ y $E)$ y se deduce cuál es la mayor tensión en valor absoluto.

La pérdida de capacidad resistente a flexión se obtiene como la relación siguiente [11]:

$$
\Delta W=\sigma_{m} / \sigma_{m, w}
$$

This operation is repeated to find the stresses for each of the five vertices of the section containing the wane $(A, B, C, D$ and $E)$ and determine the highest in absolute value.

The loss of bending strength is obtained from the following expression [11]:

Siendo $\sigma_{\mathrm{m}}$ la tensión máxima correspondiente a la sección completa. Los resultados se recogen en la Figura 12 [12].

Where $\sigma_{m}$ is the highest stress in the full section. The results are shown in Figure 12 [12].

$$
\sigma_{m}=\frac{M_{z}}{W}=\frac{6 \cdot M_{z}}{b \cdot h^{2}}
$$

\subsection{Propiedades físicas y mecánicas}

De acuerdo con la norma EN 408 (18) se obtuvo el módulo de elasticidad (módulo local - libre de cortante), la resistencia a la flexión y la densidad, Figura 13. Este

\subsection{Physical and mechanical properties}

Modulus of elasticity (local modulus - free of shear), bending strength and density values were found pursuant to European standard EN 408 [18] (Figure 13). In 
ensayo consiste en la aplicación de una carga creciente repartida en dos puntos situados en los tercios de la luz, midiendo la deformación vertical de la sección central respecto al vano central de longitud igual a 5 veces el canto de la pieza (zona libre de cortante). Para el cálculo de la tensión de rotura y del módulo de elasticidad se ha considerado la sección nominal $(b \times h)$ definida en el apartado 2.2.2.

Por otro lado, la densidad se obtuvo tomando la sección real de la pieza. Para ello se cortó una rebanada de la sección completa en una zona próxima a la sección de rotura con un espesor de $5 \mathrm{~cm}$, obteniendo su masa y volumen a partir de la planimetría de la sección. El valor obtenido de la densidad se corrigió al 12\% de contenido de humedad de acuerdo con la norma.

\section{RESULTADOS Y DISCUSIÓN}

La presencia del defecto de las gemas en la muestra estudiada es muy elevada. Del conjunto de las 84 piezas, el $61 \%$ presentaban gemas en la sección de rotura.

La aplicación de la norma de clasificación UNE 56544 presenta un rendimiento muy bajo; el porcentaje de rechazos es del 45\%, Tabla 2 . Es importante observar que el $38 \%$ del total de las piezas son rechazadas por la presencia de gemas.

El valor medio de la densidad es de $520 \mathrm{~kg} / \mathrm{m}^{3}$ con un coeficiente de variación de 0,13. El histograma de frecuencias de la densidad se muestra en la Figura 14.

Se ha realizado un análisis de la varianza para determinar si existen diferencias significativas para la tensión de rotura entre las dos especies que constituyen la muestra, obteniéndose un P-valor $=0,69$. Por tanto, los datos de resistencia de ambas especies se analizan conjuntamente. this test an increasing load is applied to two points located in such a way that they divide the span length into three equal parts. The vertical deflection is then found in the central third, whose length is five times the width (= depth) of the piece (shear-free zone). The ultimate bending strength and modulus of elasticity were calculated for the nominal section $(b \times h)$ defined in item 2.2.2.

Density, in turn, was calculated for the actual section of the piece. This involved cutting off a $5-\mathrm{cm}$ slice of the full section in an area near the section that failed and finding its mass and volume by tracing the section boundaries with a planimeter. The density value was corrected for $12 \%$ moisture content as specified in the standard.

\section{RESULTS AND DISCUSSION}

The incidence of wanes in the sample studied was high: $61 \%$ of the 84 pieces had wanes in the failure section.

Application of grading standard UNE 56544 led to very low performance, with a $45 \%$ rejection rate (Table 2$)$. And yet a highly significant $38 \%$ of the total pieces were rejected due solely to the presence of wanes.

The mean density value was $520 \mathrm{~kg} / \mathrm{m}^{3}$, with a coefficient of variation of 0.13 . The density frequency distribution is shown on the chart in Figure 14.

An ANOVA was conducted to determine whether there are statistically significant differences in the ultimate strength of both species in the sample. Inasmuch as the $P$-value found was 0.69 , the strength data for the two species were analyzed jointly.

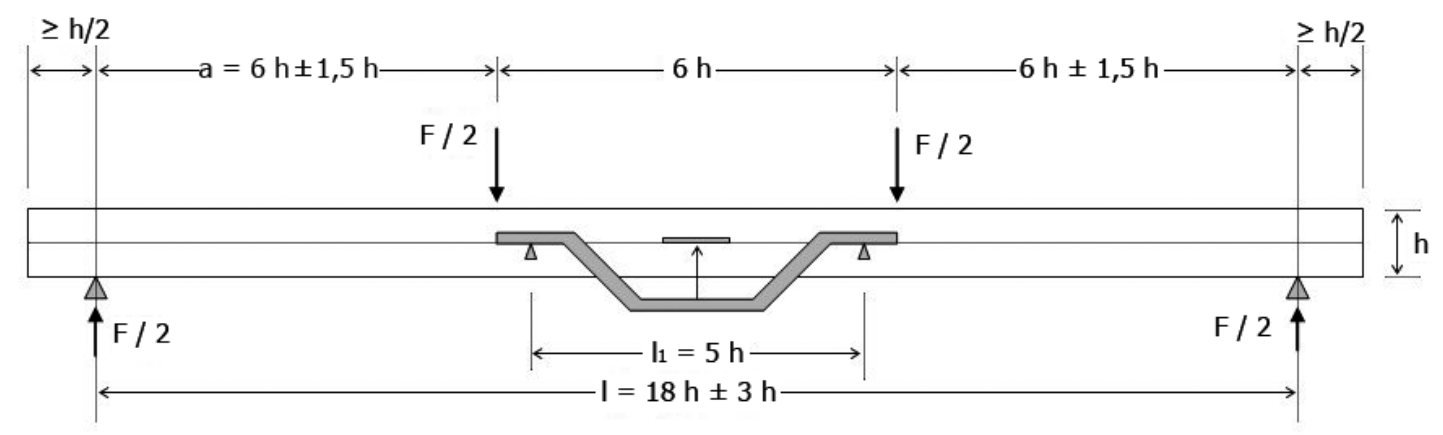

Figura 13. Ensayo de flexión.

Figure 13. Bending test. 
Con el fin de evaluar si las gemas tienen alguna repercusión en la resistencia a flexión de las piezas enterizas de madera, se procedió a dividir en tres lotes el conjunto de las 84 piezas en función del tamaño de las gemas. Para ello la clasificación se realizó en función del factor de gema $\left(k_{w}\right)$ definido en el apartado 2.2.2. De esta forma se establecen tres grupos: $A$, correspondiente a piezas sin gemas; $B$, para piezas con $k_{w} \geq 0,93$; y $C$, para piezas con $\mathrm{k}_{\mathrm{w}}<0,93$. Con este límite de $\mathrm{k}_{\mathrm{w}}$, el número de piezas de cada grupo resulta similar. En la Tabla 3 se muestran las propiedades mecánicas (obtenidas con la sección nominal) y la densidad de cada grupo.

La tensión de rotura a flexión de los tres grupos no presenta diferencias estadísticamente significativas (P-valor $=0,76)$. Por tanto, la presencia de gemas, dentro de los límites existentes en el material ensayado (con gemas que alcanzan un valor mínimo de $\mathrm{k}_{\mathrm{w}}=$ $0,683)$, no influye en la tensión de rotura nominal de las piezas.
The 84 pieces were divided into three lots based on wane size to ascertain whether the wanes impacted the bending strength of the solid timber members. The wane factor $\left(k_{w}\right)$ defined in item 2.2.2. was used for this purpose. The three groups formed were: $A$, pieces with no wanes; $B$, pieces with $k_{w} \geq 0.93$; and $C$, pieces with $k_{w}$ $<0.93$. With said $k_{w}$ cut-off value, the three groups were of similar size. Table 3 shows the mechanical properties (for the nominal section) and density for each group.

The ultimate bending strength found for the three groups showed no statistically significant differences $(P$-value $=0.76)$. Consequently, the presence of wanes, of the sizes found in the material tested (with wane factors as low as $k_{w}=0.683$ ), had no bearing on the nominal ultimate bending strength of the pieces.

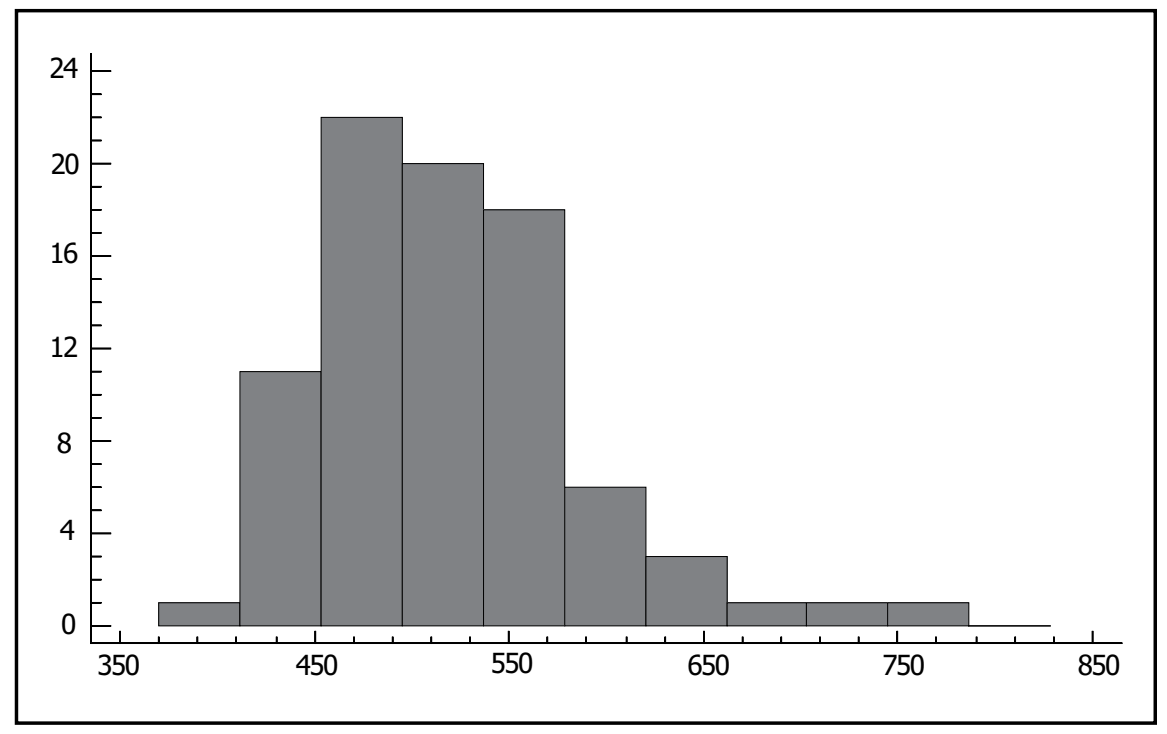

Figura 14. Histograma de frecuencias de la densidad en $\mathrm{kg} / \mathrm{m}^{3}$. Figure 14. Density frequency distribution $\left(\mathrm{kg} / \mathrm{m}^{3}\right)$.

Tabla 3 / Table 3

Propiedades mecánicas por grupos. Valores medios y coeficiente de variación de la resistencia a flexión nominal $\left(\mathrm{f}_{\mathrm{m}, 50}\right)$; módulo de elasticidad $\left(\mathrm{E}_{0, \text { mean }}\right)$; densidad $(\rho)$

Mechanical properties by group. Mean values and coefficients of variation for nominal bending strength $\left(f_{m, 50}\right)$, modulus of elasticity $\left(E_{0, \text { mean }}\right)$ and density $(\rho)$

\begin{tabular}{|c|c|c|c|c|}
\hline $\begin{array}{l}\text { Grupo } \\
\text { Group } \\
\end{array}$ & $\begin{array}{l}\text { Número de piezas } \\
\text { Number of pieces }\end{array}$ & $\begin{array}{c}f_{m, 50} \\
N / m^{2}-(\%)\end{array}$ & $\begin{array}{c}E_{0, \text { mean }} \\
\mathrm{N} / \mathrm{mm}^{2}-(\%)\end{array}$ & $\begin{array}{c}\rho \\
\mathrm{kg} / \mathrm{m}^{3}-(\%)\end{array}$ \\
\hline A (sin gemas /no wanes) & 33 & $26.0-(43.5)$ & $8289-(24.9)$ & $514-(10.8)$ \\
\hline$B\left(k_{w} \geq 0.93\right)$ & 25 & $27.8-(41.7)$ & $11453-(34.8)$ & $500-(10.59)$ \\
\hline$C\left(k_{w}<0.93\right)$ & 26 & $26.0-(25.7)$ & $10394-(38.3)$ & $548-(14.3)$ \\
\hline
\end{tabular}


El valor medio de la tensión de rotura obtenido con la sección nominal para los grupos de piezas con gemas $B$ y $\mathrm{C}$ es de 27,8 y $26 \mathrm{~N} / \mathrm{mm}^{2}$, respectivamente. Si se corrigen las tensiones de rotura de cada pieza multiplicándolas por el factor de gema $\mathrm{k}_{\mathrm{w}}$, la resistencia media obtenida para el grupo $B$ es $26,4 \mathrm{~N} / \mathrm{mm}^{2}$ y para el grupo $\mathrm{C}$ es $22,1 \mathrm{~N} / \mathrm{mm}^{2}$. Esto supone una disminución de la resistencia de hasta un $15 \%$, hecho que no se manifiesta en los resultados experimentales.

\section{CONCLUSIONES}

Las especificaciones de la norma UNE 56544 relativas a las gemas dejarían fuera de norma un elevado porcentaje $(38 \%)$ de piezas de gruesa escuadría que pueden encontrarse en estructuras existentes.

Los resultados de los ensayos mecánicos apuntan que la resistencia a flexión de las piezas con gemas no es inferior a la de las piezas libres de gemas. Esto podría explicarse por el hecho de que las fibras no se cortan en la superficie de la gema, como ocurre en las piezas de aristas vivas, así como al efecto de forma de la sección.

Es necesario profundizar en este sentido mediante la realización de un número mayor de ensayos, con el fin de confirmar los resultados obtenidos. Probablemente, estos ensayos deberían realizarse en madera aserrada nueva, para eliminar los factores presentes en la madera procedente de estructuras antiguas, que dificultan el proceso de clasificación y ensayo.

Es posible, por tanto, plantearse la posibilidad de que la clasificación visual de la madera de estructuras existentes no considere las gemas como un defecto, al menos en las magnitudes actualmente recogidas en las normas. Simplemente se debería tratar como un requisito de carácter constructivo que en el caso de estructuras construidas pierde sentido su limitación.

\section{AGRADECIMIENTOS}

Ministerio de Ciencia y Tecnología (Plan Nacional I+D+I 2000-2003. Proy.: AGL2002-00813). AITIM (Proyecto AITIM-FUCOVASA 2005-06). CIFOR-INIA, Universidad Politécnica de Madrid (ETSIM).
The mean ultimate strength values found with the nominal section for groups $B$ and $C$ were 27.8 and $26 \mathrm{~N} / \mathrm{mm}^{2}$, respectively. When the ultimate strength values found for each piece were corrected by applying wane factor $k_{w}$ the mean strength for group B was $26.4 \mathrm{~N} / \mathrm{mm}^{2}$ and for group C $22.1 \mathrm{~N} / \mathrm{mm}^{2}$. This $15 \%$ decline in strength was not reflected in the experimental results.

\section{CONCLUSIONS}

Application of the specifications on wanes laid down in standard UNE 56544 would disqualify a high percentage $(38 \%)$ of the large-section timber pieces found in existing structures.

Mechanical testing showed that the bending strength of pieces with wanes is no lower than the strength of members without this flaw. This may be due to the fact that the fibres are not interrupted along the surface of the wane as they are in sharp-edged pieces, as well as to the section shape effect.

Further information should be gathered in this regard by conducting more tests to confirm the results obtained. Such tests should probably be run on newly sawn timber to eliminate the factors present in wood from historic structures that hinder grading and testing.

Consequently, disregarding wanes as a flaw in the visual grading of existing timber structures, at least to the extent presently laid down in the applicable standards, is a possibility that may be considered. Limiting wane number and size should be regarded to be a construction requisite, which in the case of existing structures serves no practical purpose.

\section{ACKNOWLEDGEMENTS}

Ministry of Science and Technology (National R\&D+i Plan 2000-2003. Proj. AGL2002-00813). AITIM. (ATIM-FUCOVASA 2005-06). CIFOR-INIA, Universidad Politécnica de Madrid (Forestry Engineering).

\section{BIBLIOGRAFÍA / BIBLIOGRAPHY}

(1) Hankinson, R. L.: "Investigation of crushing strength of spruce at varying angles of grain. Air Service Inform", Circular III, n 259 (1921), US Air Service, Washington DC, USA. 
(2) Arriaga, F.; Esteban, M. y Relea, E.: "Evaluation of the load carrying capacity of large cross section coniferous timber in standing structures", Mater. Construcc., vol. 55, no 280 (2005), pp. 43-52.

(3) Newlin, J. A. y Trayer, G. W. (1924): "The influence of the form of a wooden beam on its stiffness and strength: II, form factors of beams subjected to transverse loading only", [U.S.] Natl. Advisory Com. Aeronautics Ann. Rept. (1923) 9 (Tech. Rept. 181), pp. 373-393, ilus.

(4) Lee, S.-M.; Abbott, A. L.; Schmoldt, D. L. y Araman, P. A.: "A system for optimal edging and trimming of rough hardwood lumber", Proceedings of the Fifth International Conference on Image Processing and Scanning of Wood. March, 23-26, 2003, Bad Waltersdorf, Austria, pp. 25-34.

(5) Mohamed, F.; Schmolt, D.; Araman, P. Schafer, M. y Lee, S. M.: "Classifying defects in pallet stringers by ultrasonic scanning", Wood and Fiber Science, 35 (3) (2003), pp. 341-350.

(6) Reddy, V. y Bush, R.: "Measuring softwood lumber value: a conjoint analysis approach", Forest Science, 44 (1) (1998), pp. $145-157$. (7) Stojanovic, R.; Koubias, S.; Stojanovic, E. y Georgoudakis, M.: "A Measuring Method for Laser-Based Profilometry and Its Application in Non-Destructive Testing and Quality Control", Proceedings of the $4^{\text {th }}$ Intern. Conference on Vibration Measurements by Laser Techniques - Advances \& Applications, Ancona, Italy, July, 18-21, 2002.

(8) Quin, F. Jr. Steele, P. y Shmulsky, R.: "Locating knots in wood with an infrared detector system. Solid wood products", vol. 48, no 10, October, 1998, pp. 80-84.

(9) Beard, J. S.; Wagner, F. G.; Taylor, F. W. y Seale, R. D.: "The influence of growth characteristics on warp in two structural grades of southern pine lumber", Forest Products Journal, vol. 43, no 6 (1993), pp. 51-56.

(10) Johansson, M. y Kliger, R.: "Influence of material characteristics on warp in norway spruce studs", Wood and Fiber Science, 34(2) (2002), pp. 325-336.

(11) Oliver-Villanueva, J.-V.; Quer, M. y Becker, G.: Influence of structural parameters on nondesrtuctive evaluation of ash timber (Fraxinus excelsior L.), Holz als Roh und Werkstoff, no 54 (1996), pp. 109-112.

(12) Hui, Z. y Smith, I.: "Factors influencing bending properties of white spruce lumber", Wood and Fiber Science, 23(4) (1991), pp. 483-500.

(13) Zhou, H. y Smith, I.: "Factors influencing bending properties of white spruce lumber", Wood and Fiber Science, 23(4) (1991), pp. $483-500$.

(14) Wolfe, R. y Murphy, J. (2005): "Strength of small-diameter round and tapered bending members", Forest Products Journal, vol. 55, no 3, pp. 50-55.

(15) UNE 56544: Clasificación visual de la madera aserrada para uso estructural. Madera de coníferas (Visual grading of sawn timber for structural use. Coniferous), 2003.

(16) DIN 4074: Sortierung von Holz nach der Tragfähigkeit. Teil 1: Nadelschnittholz (Strength grading of wood. Part 1: coniferous sawn timber), 2003.

(17) EN 14081-1: Timber structures. Strength graded structural timber with rectangular cross section. Part 1: General requirements. October, 2002.

(18) EN 408: Timber structures. Sawn timber and glued laminated timber for structural use. Determination of some physical and mechanical properties, 1999. 